\title{
Efektifitas Penggunaan Media Mobile Learning berbasis Android Terhadap Hasil Belajar Mahasiswa IKIP Budi Utomo Malang
}

Muhammad Naharuddin Arsyad, Dinna Eka Graha Lestari

Program Studi Pendidikan Sejarah dan Sosiologi, Fakultas Pendidikan Ilmu Sosial dan Humaniora, IKIP Budi Utomo Malang

\begin{abstract}
Abstrak
Penelitian ini bertujuan untuk mengetahui efektivitas penggunaan media mobile learning berbasis android materi sejarah revolusi industri di Eropa terhadap peningkatan hasil belajar mahasiswa IKIP Budi Utomo Malang. Metode yang digunakan adalah eksperimen, dengan desain penelitian one group pretest posttest design. Populasi penelitian adalah mahasiswa angkatan 2017 kelas A Program Studi Sejarah dan Sosiologi IKIP Budi Utomo Malang. Pengambilan sampel dengan menggunakan teknik purposive sampling. Dari hasil uji kolmogorov-smirnov dengan menggunakan SPSS 14 diperoleh bahwa subjek penelitian terdistribusi normal dan berdasarkan hasil uji-t Paired Samples Test diketahui bahwa nilai sig sebesar 0,000 >0,05. Sedangkan $t_{\text {hitung }}=-12,692$ dan untuk $t_{\text {tabel }}$ pada taraf signifikan $\alpha=5 \%$ $(0,05)$ dengan derajat kebebasan (df) $n-1$ atau 45-1 = 44. Pengujian 2 sisi (signifikansi $=0,025)$ hasil diperoleh untuk $t_{\text {tabel }}=2,01537$ dengan taraf signifikan 0,025. Di dapatkan hasil - $t_{\text {hitung }}<-$ $t_{\text {tabel }}(-12,692<-2,01537)$ maka HO ditolak dan Ha diterima. Sehingga penggunaan media mobile learning berbasis android materi sejarah revolusi industri Eropa dapat meningkatkan hasil belajar mahasiswa prodi sejarah dan sosiologi IKIP Budi Utomo Malang.
\end{abstract}

Kata Kunci: Mobile learning, Android, Hasil belajar

\section{Pendahuluan}

Pendidikan adalah usaha yang dilakukan secara sadar dan terencana untuk mewujudkan suasana dan proses pembelajaran yang aktif bagi peserta didik. Supaya mampu mengembangkan potensi dalam dirinya, seperti kepribadian baik, pengendalian diri, berakhlak mulia, kecerdasan, dan keterampilan yang diperlukan dirinya dan masyarakat. Dari pengertian tersebut terlihat bahwa pendidikan merupakan proses yang penting dalam kehidupan. Tujuannya untuk mengetahui kemampuan dan tingkah laku peserta didik dalam melakukan hal baik atau buruk. Selanjutnya, di Indonesia khususnya di bidang pendidikan mulai ditingkatkan. Salah satunya dengan cara melengkapi sarana dan prasarana penunjang pembelajaran. Misalnya, penggunaan media pembelajaran. Media pembelajaran merupakan alat bantu mengajar bagi pendidik guna menyampaikan materi pengajaran. Sehingga diharapkan dapat meningkatkan kreatifitas dan perhatian peserta didik dalam pelaksanaan pembelajaran. Dengan media pembelajaran, peserta didik akan lebih termotivasi untuk belajar, mendorong mereka untuk menulis, berbicara dan berimajinasi. Dengan demikian, melalui media pembelajaran tersebut bisa membuat proses belajar mengajar lebih efektif, efesien, serta terjalin hubungan baik antara pendidik dengan peserta didik. Selain itu, media pembelajaran dapat 
berperan untuk mengatasi kebosanan dalam belajar di dalam kelas. Oleh karena itu, pendidik dituntut untuk memberikan motivasi pada peserta didik melalui pemanfaatan media pembelajaran yang tidak hanya ada di dalam kelas, tetapi juga di luar kelas. Apabila ini bisa dimanfaatkan maka tujuan pembelajaran akan tercapai. Lantas apa yang terjadi jika media pembelajaran tidak ada. Maka yang terjadi adalah peserta didik akan mengalami kesulitan dalam mengajar, materi menjadi monoton dan merasa bosan dengan apa yang diajar oleh pendidik.

Oleh karena itu, media pembelajaran harus difungsikan untuk meningkatkan kualitas belajar mengajar. Dengan demikian semakin menarik media pembelajaran yang digunakan oleh pendidik akan semakin tinggi pula tingkat motivasi belajar peserta didik. Namun dalam prakteknya, masih banyak dijumpai para pendidik yang sudah menerapkan media pembelajaran. Namun belum dapat mencapai tujuan pembelajaran itu sendiri, karena media pembelajaran yang digunakan tidak bervariasi.

Hal ini diperlukan suatu penemuan dan pengembangan baru mengenai media pembelajaran. Salah satu contoh bentuk media pembelajaran baru yang bisa digunakan adalah media mobile learning. Media ini dirancang untuk mempermudah setiap manusia melakukan pembelajaran secara bebas, kapan pun dan dimana pun berada. Pembelajaran mobile learning adalah bentuk pembelajaran yang khusus memanfaatkan perangkat dan teknologi komunikasi bergerak. Pembelajaran mobile learning dapat diakses dengan mudah, karena kecanggihan teknologi yang semakin pesat berkembang, seperti smartphone. Smartphone atau ponsel cerdas adalah alat komunikasi yang menyerupai komputer, tetapi lebih praktis dan dapat digunakan dimana saja. Dalam hal ini smartphone mempermudah pendidikan di Indonesia untuk menjalankan program pembelajaran online atau pun offline.

Fakta yang terjadi ternyata masih banyak mahasiswa yang memanfaatkan smartphone hanya sebagai media komunikasi dan bermain saja. Padahal peningkatan mutu pendidikan dapat pula dilakukan dengan memanfaatkan mobile learning sebagai media pembelajaran yang dapat merubah paradigma mahasiswa tentang pembelajaran di kelas. Pembelajaran yang hanya duduk untuk mendengarkan dan mengikuti pengajaran yang sudah diketahui dosen.

Penggunaan mobile learning berbasis android diharapkan bisa membuat proses pembelajaran lebih efektif, efisien dan menyenangkan pada mata kuliah sejarah Eropa. Khususnya materi revolusi industri Eropa yang banyak menggunakan gambar, audio, video maupun animasi. Adapun hasil analisis kebutuhan yang telah 
dilakukan peneliti di IKIP Budi Utomo Malang Program Studi Pendidikan Sejarah dan Sosiologi pada mahasiswa angkatan 2017 kelas A dengan jumlah 45 mahasiswa melalui observasi, hasilnya $100 \%$ mahasiswa memiliki smartphone. Selain itu, $90 \%$ mahasiswa dapat menggunakan smartphone dengan baik. Berdasarkan hasil analisis pengamatan kepada Dosen menunjukkan bahwa rerata hanya menggunakan sarana media LCD proyektor dan merangkum materi ke slide powerpoint. Ada juga yang hanya menggunakan modul berbasis cetak.

Berdasarkan hasil pengamatan kebutuhan mahasiswa diketahui 65\% lebih mahasiswa masih kurang memahami materi pada mata kuliah sejarah Eropa ketika menggunakan media LCD proyektor. Mahasiswa cenderung merasa bosan dengan pembelajaran yang diterapkan Dosen yang hanya menggunakan metode ceramah dan diskusi. Oleh karena itu, untuk meningkatkan gairah belajar dan pemahaman mahasiswa terhadap mata kuliah sejarah Eropa materi revolusi industri Eropa, maka mengembangkan media mobile learning berbasis android.

\section{Tinjauan Pustaka}

\section{A. Media Pembelajaran}

Kata media berasal dari bahasa Latin medius yang secara harfiah berarti tengah, perantara, atau pengantar (Arsyad, 2006). Suranto (2005) menjelaskan media adalah sarana yang digunakan untuk menyampaikan pesan dari seorang komunikator kepada komunikan. Lebih lanjut, Sutirman (2013) berpendapat media merupakan komponen sumber belajar atau wahana fisik yang mengandung materi instruksional di lingkungan siswa, yang dapat merangsang siswa untuk belajar. Pendapat lain dikemukakan Sardiman (1992), media adalah sesuatu yang dapat digunakan untuk menyalurkan pesan dari pengirim ke penerima, sehingga merangsang pikiran, perasaan, perhatian, minat serta perhatian siswa sedemikian rupa sehingga proses belajar terjadi.

Sementara itu, Sukiman (2012) menjelaskan yang dimaksud dengan media adalah segala sesuatu untuk menyalurkan pesan dari pengirim ke penerima, sehingga merangsang pikiran, perasaan, perhatian dan minat serta kemauan peserta didik, sehingga proses belajar terjadi dalam rangka mencapai tujuan pembelajaran secara efektif. Dengan demikian media pembelajaran adalah perantara, instrumen dan alat yang digunakan pendidik untuk menyampaikan informasi atau pelajaran.

Dengan tujuan supaya merangsang peserta didik untuk belajar. Penggunaan media pembelajaran merupakan cara yang dilakukan untuk menyampaikan informasi berupa materi pembelajaran. Dengan adanya media proses pembelajaran akan lebih mudah bagi peserta didik. Oleh karena media pembelajaran dapat 
mengatasi keterbatasan ruang dan waktu dalam belajar. Selain dapat memberikan motivasi bagi peserta didik untuk belajar. Sukiman (2012) mengemukakan manfaat media pembelajaran dalam proses belajar mengajar, yaitu:

1. Media pembelajaran dapat memperjelas penyajian pesan dan informasi sehingga dapat memperlancar dan meningkatkan proses dan hasil belajar.

2. Media pembelajaran dapat meningkatkan dan mengarahkan perhatian anak, sehingga menimbulkan motivasi belajar, interaksi dengan lingkungan dan untuk belajar mandiri sesuai kemampuan dan minatnya.

3. Media pembelajaran dapat mengatasi keterbatasan indera, ruang dan waktu.

Dalam proses belajar mengajar seorang pendidik hendaknya terampil dalam memilih, menggunakan dan menyesuaikan media pembelajaran yang digunakan. Dalam masalah ini ada beberapa hal yang perlu diperhatikan dalam penguasaan pengetahuan tentang media pembelajaran, untuk meningkatkan kualitas dan efektifitas pengajaran tersebut, yaitu: Pertama, pendidik perlu memiliki pemahaman media pembelajaran antara lain jenis dan manfaat media, kriteria memilih dan menggunakan media, menggunakan media sebagai alat bantu mengajar dan tindak lanjut penggunaan media dalam proses belajar peserta didik. Kedua, pendidik terampil membuat media pembelajaran sederhana untuk keperluan pengajaran, terutama media dua dimensi atau media grafis dan beberapa media tiga dimensi serta media proyeksi. Ketiga, pendidik memiliki pengetahuan dan keterampilan dalam menilai keefektifan penggunaan media pembelajaran dalam proses pengajaran.

Media pembelajaran yang digunakan dalam proses pembelajaran dapat dibedakan menjadi beberapa macam, yaitu:

1. Media cetak meliputi modul, handout, buku teks, majalah, koran.

2. Media visual meliputi film, lukisan, foto, gambar, diagram, grafik.

3. Media audio meliputi radio, telepon, tape recorder.

4. Media audio-visual meliputi televisi, video, dan film.

5. Media berbasis aplikasi, yakni video interaktif, media berbasis komputer, media berbasis web, media berbasis android.

Media pembelajaran merupakan komponen pembelajaran yang perlu pertimbangan dalam memilih supaya berfungsi secara efektif. Pemilihan media pembelajaran dapat dilakukan dengan mempertimbangkan faktor:

1. Hambatan pengembangan dan pembelajaran, seperti dana, fasilitas dan peralatan, waktu, dan sumber-sumber yang tersedia. 
2. Persyaratan isi, tugas dan jenis pembelajaran.

3. Hambatan dari sisi siswa dengan mempertimbangkan kemampuan dan keterampilan awal.

4. Tingkat kesenangan dan keefektifan biaya.

5. Pemilihan media sebaiknya mempertimbangkan kemampuan akomodasi penyajian stimulus yang tepat, respon siswa yang tepat, umpan balik, serta pemilihan media utama dan sekunder untuk penyajian informasi atau stimulus, latihan dan tes.

Media sekunder harus mendapat perhatian, sebab pembelajaran yang berhasil menggunakan media yang beragam (Arsyad, 2006).

\section{B. Mobile Learning}

Mobile learning adalah pembelajaran yang memanfaatkan teknologi dan perangkat mobile. Pengertian mobile learning menurut $0^{\prime}$ Malley menjelaskan bahwa mobile learning adalah pembelajaran apapun yang terjadi ketika pelajar tidak pada lokasi yang tetap atau telah ditentukan, dan pembelajaran yang terjadi ketika pelajar mengambil keuntungan dari kesempatan belajar yang ditawarkan oleh teknologi mobile.

Menurut Meilana (2017) juga menyiratkan bahwa mobile learning itu merupakan konsep belajar jarak jauh dengan menggunakan teknologi telekomunikasi dan informasi. Dari beberapa pendapat ahli mengenai definisi mobile learning, dapat ditarik satu ringkasan yang menjelaskan bahwa model pembelajaran yang memanfaatkan teknologi informasi dan komunikasi. Pada konsep pembelajaran tersebut mobile learning membawa manfaat ketersediaan materi ajar yang dapat diakses setiap saat dan visualisasi materi yang menarik.

Istilah m-learning atau mobile learning merujuk pada penggunaan perangkat genggam seperti PDA, ponsel, laptop dan perangkat teknologi informasi yang banyak digunakan dalam belajar mengajar. Dalam hal ini difokuskan pada perangkat handphone (telepon genggam). Menurut Meilana (2017) ada tiga fungsi $m$ learning dalam kegiatan pembelajaran, yaitu sebagai tambahan yang sifatnya suplement, complement, atau substitusi.

1. Suplement

M-Learning berfungsi sebagai suplement (tambahan), yaitu peserta didik mempunyai kebebasan memilih, apakah akan memanfaatkan materi $M$ Learning atau tidak. Dalam hal ini, tidak ada kewajiban peserta didik untuk mengakses materi M-Learning. Sekalipun sifatnya opsional, peserta didik yang memanfaatkan akan memiliki tambahan pengetahuan.

\section{Complement}

M-Learning berfungsi sebagai pelengkap, yaitu materi diprogramkan untuk melengkapi materi pembelajaran 
yang diterima peserta didik dalam kelas.

Materi M-Learning berarti diprogram untuk menjadi materi penguatan atau remedial di dalam kegiatan pembelajaran konvensional.

3. Substitusi

Beberapa Perguruan Tinggi di Negara maju memberikan alternatif model kegiatan pembelajaran ke peserta didik. Tujuannya supaya mereka secara fleksibel dapat mengelola kegiatan perkuliahan sesuai waktu dan aktifitas sehari-hari. Terdapat tiga alternatif model kegiatan pembelajaran yang dapat dipilih peserta didik, yaitu sepenuhnya secara tatap muka (konvensional), sebagian secara tatap muka dan sebagian lagi melalui internet, serta sepenuhnya melalui internet.

\section{Android}

Menurut Arifianto (2011) android merupakan perangkat bergerak pada sistem operasi untuk telepon seluler yang berbasis linux. Adapun pengertian android adalah sistem operasi untuk smartphone dan tablet (Satyaputra dan Aritonang, 2014). Era modern ini akan di dominasi kecanggihan teknologi. Seperti android yang tidak hanya bisa di nikmati di smartphone atau tablet, melainkan sudah bisa digunakan di komputer atau laptop. Sifat sistem android sendiri bersifat open source. Di mana ahli program atau yang biasa disebut programer banyak membuat aplikasi dan memodifikasi aplikasi pada android. Keterlibatan programmer memiliki peran yang penting untuk mengembangkan android. Sebab sistem android dibuat secara open source. Pengguna smartphone dapat menikmati aplikasi yang dibuat oleh programmer secara gratis atau berbayar di play store. Semakin banyak masyarakat yang memiliki dan menggunakan perangkat mobile smartphone, membuka peluang penggunaan perangkat teknologi bergerak dalam dunia pendidikan.

Huda (2013) mengemukakan dalam sistem android terdapat beberapa komponen penting. Komponen tersebut saling berhubungan tetapi memiliki fungsi yang berbeda. Adapun komponen tersebut, yaitu:

\section{Activitity}

Activity merupakan satu halaman antarmuka yang digunakan oleh user untuk berinteraski dengan aplikasi. Biasanya dalam satu activity terdapat button, spinner, list view, edit text dan sebagainya. Satu aplikasi dalam Android dapat terdiri atas lebih dari satu activity.

2. Services

Services adalah komponen aplikasi yang dapat berjalan secara background. Misalnya, memuat data server database. Selain itu, aplikasi pemutar musik atau radio memanfaatkan servis agar aplikasi bisa berjalan, meski pengguna melakukan aktivitas dengan aplikasi lain. 


\section{Contact Provider}

Komponen ini untuk mengelola data aplikasi, misalnya kontak telepon. Siapa pun bisa membuat aplikasi Android dan dapat mengakses kontak yang tersimpan. Oleh karena itu, supaya dapat mengakses kontak, user memerlukan komponen contact provider.

\section{Broadcast Receiver}

Fungsi komponen ini sama seperti bahasa terjemahannya yaitu penerima pesan. Kasus beterai lemah merupakan kasus yang sering dialami handphone Android. Sistem android dirancang untuk menyampaikan pengumuman otomatis jika baterai habis. Apabila aplikasi yang dibuat dilengkapi dengan komponen broadcast receiver, maka user dapat mengambil tindakan menyimpan kemudian menutup aplikasi atau tindakan yang lain.

\section{Hasil Belajar}

Hasil belajar berasal dari dua kata, yakni hasil dan belajar. Belajar merupakan proses perubahan tingkah laku melalui latihan, keterampilan dan pengalaman (Cholil \& Kurniawan, 2011). Pengertian hasil menunjuk perolehan akibat dilakukan aktivitas atau yang mengakibatkan perubahan input secara fungsional. Hasil belajar sebagai perubahan yang mengakibatkan manusia berubah dalam sikap dan tingkah laku. Aspek perubahan mengacu kepada taksonomi bloom, yaitu aspek kognitif, afektif dan psikomotorik (Rusman, 2012). Lebih lanjut, hasil belajar merupakan kemampuan yang dimiliki peserta didik setelah menerima pengalaman belajarnya. Hasil belajar mempunyai peranan penting dalam proses pembelajaran. Proses penilaian terhadap hasil belajar dapat memberikan informasi kepada pendidik tentang kemajuan peserta didik. Sebagai upaya mencapai tujuantujuan belajar melalui kegiatan pembelajaran. Berhasil atau tidaknya peserta didik dalam belajar dipengaruhi oleh beberapa faktor.

Faktor tersebut mempengaruhi pencapaian hasil belajar siswa. Menurut Slameto (2010) faktor yang mempengaruhi hasil belajar digolongkan menjadi dua:

1. Faktor intern

a) Faktor jasmaniah: Faktor jasmaniah mempengaruhi mencakup faktor kesehatan dan cacat tubuh.

b) Faktor psikologis: Faktor psikologis yang mempengaruhi mencakup intelegensi, perhatian, minat, bakat, motif, kematangan dan kesiapan.

c) Faktor kelelahan: Ada dua kelelahan seseorang, yaitu kelelahan jasmani dan rohani (psikis).

2. Faktor-faktor ekstern

a) Faktor keluarga: Siswa menerima pengaruh dari keluarga berupa cara orang tua mendidik, relasi antara anggota keluarga, suasana rumah 
tangga dan keadaan ekonomi keluarga.

b) Faktor sekolah: Faktor sekolah yang mempengaruhi mencakup metode mengajar, kurikulum, relasi guru dengan siswa, disiplin, alat pelajaran, waktu, standar pengajaran, gedung, metode belajar dan tugas rumah.

c) Faktor masyarakat: Faktor masyarakat yang mempengaruhi kegiatan siswa dalam masyarakat, media masa, teman bergaul dan bentuk kehidupan masyarakat.

\section{Metode Penelitian}

Penelitian ini menggunakan metode eksperimen. Penelitian eksperimen adalah metode penelitian yang digunakan untuk mencari pengaruh perlakuan tertentu terhadap yang lain dalam kondisi yang terkendalikan (Sugiyono, 2014). Adapun desain penelitian yang digunakan adalah one group pre-test post-test design. Sebelum perlakuan terhadap sampel terlebih dahulu diberi tes awal dan diakhir pembelajaran atau sesudah perlakuan sampel diberi tes akhir. Untuk lebih jelas mengenai desain penelitian, ditunjukkan pada gambar 1 .

\section{$\begin{array}{lll}\mathbf{O}_{1} & \mathbf{x} & \mathbf{O}_{2}\end{array}$}

Gambar 1: Desain Eksperimen before-after (Sugiyono, 2014)

Keterangan:

01 = nilai sebelum treatment

02 = nilai sesudah treatment

$\mathrm{X}=$ perlakuan terhadap eksperimen
Populasi penelitian adalah mahasiswa angkatan 2017 dengan 3 kelas. Teknik pengambilan sampel yang digunakan, yaitu purposive sampling. Dari teknik tersebut sampel yang terpilih adalah kelas A angkatan 2017 sebanyak 45 mahasiswa. Instrumen yang digunakan untuk mengumpulkan data adalah pedoman observasi, angket, tes dan dokumentasi. Analisis data kuantitatif yang digunakan untuk mengetahui efektifitas media mobile learning adalah menggunakan analisis $t$-test dengan tingkat kemaknaan 0,05\%. Rumus yang digunakan seperti ditunjukkan pada gambar 2 .

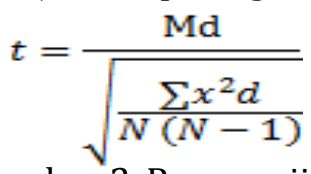

Gambar 2. Rumus uji t-test

(Suharsimi, 2013)

Keterangan:

$\mathrm{T}=\mathrm{Uji}-\mathrm{T}$

$\mathrm{Md}=$ Mean dari perbedaan pre-test dan post-test $\left(\mathrm{x}_{2}-\mathrm{x}_{1}\right)$

$\mathrm{xd}=$ deviasi masing-masing subjek $(\mathrm{d}$ $\mathrm{Md})$

$\sum \mathrm{x}^{2} \mathrm{~d}=$ Jumlah kuadrat deviasi

$\mathrm{N} \quad=$ Subjek pada sampel

d.b $=$ Ditentukan dengan $\mathrm{N}-1$

Untuk mengetahui tingkat kevalidan, menggunakan konversi skala tingkat yang telah ditetapkan. Adapun pedoman ditunjukkan pada tabel 1.

Tabel 1. Tingkat kevalidan

\begin{tabular}{cc}
\hline $\begin{array}{c}\text { Tingkat pencapaian } \\
\text { (\%) }\end{array}$ & Kriteria kevalidan \\
\hline $0-20$ & Tidak valid \\
$21-40$ & Kurang valid \\
$41-60$ & Cukup valid \\
$61-80$ & Valid \\
$81-100$ & Sangat valid \\
\hline \multicolumn{2}{c}{ (Dokumentasi Peneliti) }
\end{tabular}




\section{Hasil Dan Pembahasan}

Efektifitas penggunaan media mobile learning berbasis android terhadap hasil belajar pada materi sejarah revolusi industri di Eropa, dapat diketahui dengan mengetahui perbandingan hasil belajar sebelum penerapan pre-test. Dengan penerapan post-test, media mobile learning berbasis android yang dilakukan terhadap mahasiswa Program Studi pendidikan Sejarah dan Sosiologi IKIP Budi Utomo
Malang angkatan 2017 kelas A sebanyak 45 mahasiswa. Ada 3 pertemuan dalam penelitian ini yaitu implementasi 1 yang membahas sub materi latar belakang dan faktor terjadinya revolusi industri di Eropa, implementasi 2 yang membahas sub materi wujud dan dampak revolusi industri di Eropa dan pertemuan terakhir adalah evaluasi pembelajaran atau post-test. Tabel 2 menunjukkan hasil Uji coba tersebut.

Tabel 2. Statistik Deskripstif

\begin{tabular}{lccccc}
\hline & N & Min & Max & Mean & Std. Deviation \\
\hline Pre_test & 45 & 50,00 & 85,00 & 69,33 & 8,89331 \\
Post_test & 45 & 70,00 & 95,00 & 81,33 & 6,60578 \\
N_gain & 45 &, 00 & 25,00 & 12,00 & 6,34250 \\
\hline
\end{tabular}

Berdasarkan tabel 2, diketahui hasil rata-rata pre-test dan post-test mahasiswa yang berbeda. Hasil perolehan nilai rerata pre-test mahasiswa adalah 69,33 sedangkan hasil post-test mahasiswa adalah 81,33. Hal ini menunjukkan nilai post-test lebih baik dari pada nilai pre-test yaitu 81,33 > 69,33. Secara umum mahasiswa mengalami peningkatan hasil belajar rata-rata sebesar 12 . Sehingga ada perbedaan nilai rerata hasil penggunaan produk pengembangan media mobile learning yang dilakukan peneliti. Untuk lebih memperkuat hasil analisa, maka dilakukan analisis uji-t yaitu paired sample test dengan membuat hipotesis:

Ha : Terdapat perbedaan yang signifikan pada hasil belajar mahasiswa sebelum dan sesudah menggunakan media mobile learning berbasis android

Ho : Tidak terdapat perbedaan yang signifikan pada hasil belajar mahasiswa sebelum dan sesudah menggunakan media mobile learning berbasis android

Selanjutnya melakukan uji perbedaan dua rata-rata dengan uji-t. Namun sebelumnya, terlebih dahulu dilakukan uji normalitas data dari nilai pretest dan nilai post-test. Normalitas data nilai hasil tes dalam penelitian merupakan persyaratan yang harus dipenuhi untuk melakukan analisis inferensial, dengan menggunakan teknik statistik parametrik. Hasil uji terhadap hasil belajar mahasiswa nilai pre-test maupun post-test dilakukan dengan menggunakan program SPSS 14. 
Tabel 3. Hasil Perhitungan One-Sample Kolmogorov-Smirnov Test

\begin{tabular}{llrr}
\hline & & Pre_Test & Post_Test \\
\hline $\mathrm{N}$ & & 45 & 45 \\
Normal Parameters (a,b) & Mean & 69,33 & 81,33 \\
& Std. Deviation & 8,893 & 6,605 \\
Most Extreme Differences & Absolute &, 174 &, 180 \\
& Positive &, 115 &, 180 \\
& Negative &,- 174 &,- 131 \\
Kolmogorov-Smirnov Z & & 1,169 & 1,207 \\
Asymp. Sig. (2-tailed) & &, 130 &, 108 \\
\hline
\end{tabular}

a Test distribution is Normal.

b Calculated from data.

(Dokumentasi Peneliti)

Hasil uji normalitas dengan signifikan antara nilai rata-rata mahasiswa menggunakan one sample kolmogorov- sebelum dengan sesudah mengikuti smirnov test terhadap nilai pre-test dan nilai post-test mahasiswa pada tabel 3 diperoleh nilai signifikan lebih besar dari 0,05 , yaitu pre-test sebesar 0,130 dan post-test sebesar 0,108. Nilai tersebut lebih besar dari taraf nyata 0,05 yakni 0,130 dan $0,108>0,05$.

Hal tersebut berarti subjek pembelajaran dengan menggunakan media mobile learning berbasis android. Uji-t (Paired Sample Test) dilakukan dengan menggunakan SPSS 14 dengan taraf kepercayaan 95\% atau signifikansi 0,05. Hasil uji Paired Sample Test seperti ditunjukkan pada tabel 4.

penelitian berdistribusi normal dan syarat untuk melakukan analisis uji Paired Sample Test telah terpenuhi. Langkah selanjutnya adalah menganalisis data nilai pre-test dan post-test yang dilakukan dengan uji Paired Sample Test. Hal ini dilakukan untuk mengetahui apakah terjadi perbedaan yang

Tabel 4. Hasil Uji Paired Samples Test

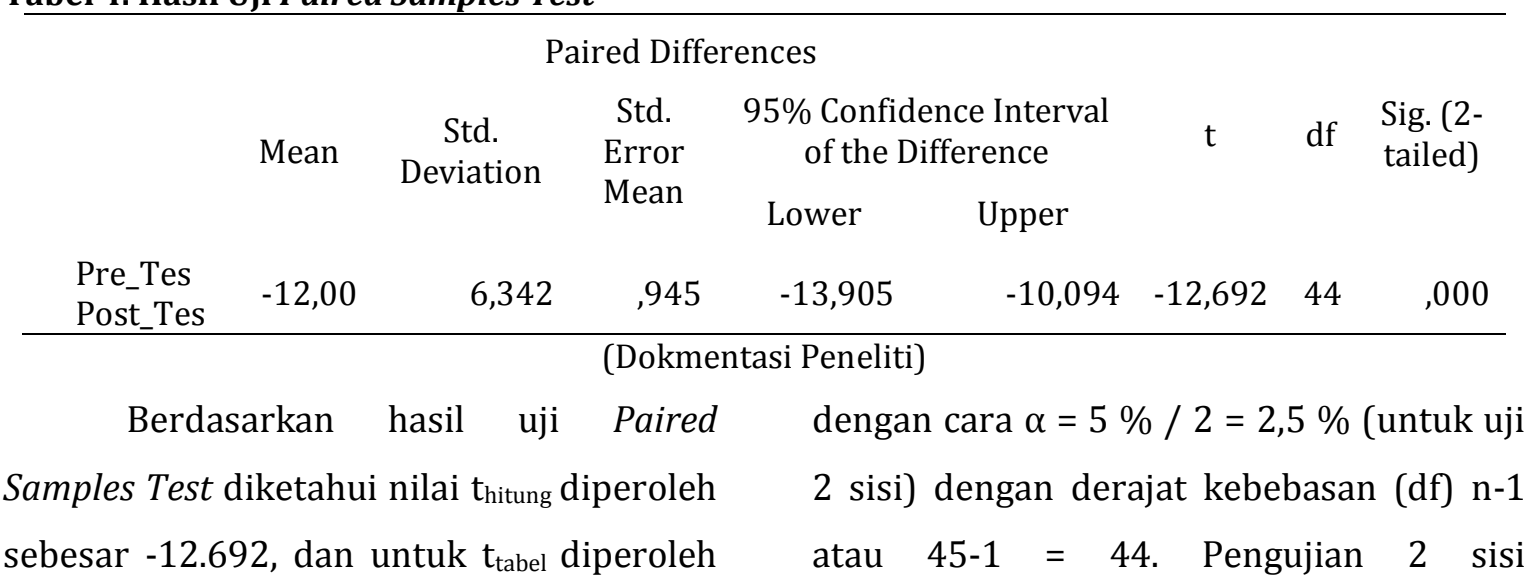


(signifikansi $=0,025)$ dengan hasil perolehan $t_{\text {tabel }}$ pada 2,01537 dengan taraf signifikan 0,025. Hasilnya menunjukkan $\mathrm{t}_{\text {hitung }}<-\mathrm{t}_{\text {tabel }}(-12.692<-2,01537) . \mathrm{T}_{\text {hitung }}$ bernilai negatif, sehingga nilai rerata pretest lebih rendah dari nilai rerata post-test.

Oleh karena nilai sig. (2-tailed) 0,000 lebih besar dari 0,05 , dapat disimpulkan Ho ditolak dan Ha diterima. Sehingga uraian tersebut dapat diartikan terdapat perbedaan yang signifikan antara hasil belajar sebelum dan setelah penerapan media mobile learning berbasis android materi sejarah revolusi industri Eropa. Sehingga secara efektif bisa meningkatkan hasil belajar mahasiswa. Adapun manfaat dari media pembelajaran menurut Yamin (2006) yaitu:

A. Penyampaian materi pembelajaran dapat diseragamkan

Setiap peserta didik mempunyai penafsiran yang berbeda-beda terhadap konsep materi pelajaran tertentu. Dengan bantuan media, penafsiran yang beragam dapat terhindarkan, sehingga dapat disampaikan kepada peserta didik secara seragam. Setiap peserta didik yang melihat atau mendengar uraian materi pelajaran melalui media yang sama, akan menerima informasi yang sama seperti yang diterima peserta didik yang lain. Dengan demikian, media juga dapat mengurangi terjadinya kesenjangan informasi dimana pun berada.
B. Proses pembelajaran menjadi lebih menarik dan jelas

Dengan berbagai potensi yang dimiliki peserta didik, media dapat menampilkan informasi melalui audio, visual, animasi dan warna baik alami maupun manipulasi. Materi pelajaran yang dikemas melalui program media lebih jelas, lengkap, serta menarik minat peserta didik. Dengan media pembelajaran, materi sajian bisa membangkitkan rasa ingin tahu peserta didik. Bahkan bisa merangsang mereka untuk bereaksi secara fisik dan emosional. Artinya, media pembelajaran dapat membantu dalam menciptakan suasana pembelajaran lebih hidup, tidak monoton dan tidak membosankan.

C. Efisiensi waktu dan tenaga

Keluhan yang selama ini sering di dengar dari pendidik adalah selalu kekurangan waktu untuk mencapai target kurikulum. Sering terjadi pendidik menghabiskan waktu untuk menjelaskan materi pelajaran. Hal ini sebenarnya tidak harus terjadi jika dapat memanfaatkan media secara maksimal. Misalnya, tanpa media pendidik tentu akan menghabiskan waktu untuk menjelaskan sistem peredaran darah manusia atau proses terjadinya gerhana matahari.

Padahal dengan bantuan media visual, topik ini dengan cepat dijelaskan kepada peserta didik. Biarkan media 
menyajikan materi pelajaran yang sulit untuk disajikan secara verbal. Dengan media, tujuan belajar akan lebih mudah tercapai secara maksimal dengan waktu dan tenaga seminimal mungkin. Dengan media, pendidik tidak harus menjelaskan materi pelajaran berulangulang. Sebab hanya dengan sekali sajian menggunakan media, peserta didik lebih mudah memahami pelajaran.

D. Meningkatkan kualitas hasil belajar peserta didik

Penggunaan media bukan hanya membuat proses pembelajaran lebih efisien, tetapi membantu peserta didik menyerap materi lebih utuh. Bila hanya mendengarkan informasi verbal, mungkin kurang memahami pembelajaran dengan baik. Tetapi jika diperkaya dengan kegiatan melihat, menyentuh, merasakan atau mengalami sendiri melalui media, pemahaman peserta didik menjadi lebih baik.

E. Media memungkinkan proses pembelajaran dilakukan kapan saja.

Media pembelajaran dapat di desain dan dirancang. Sehingga peserta didik dapat melakukan kegiatan pembelajaran secara leluasa, kapan dan dimana pun. Tanpa tergantung keberadaan seorang pendidik. Program pembelajaran audio visual seperti komputer, memungkinkan peserta didik dapat melakukan kegiatan pembelajaran mandiri, tanpa terikat waktu dan juga tempat. Penggunaan media dapat menyadarkan peserta didik betapa banyak sumber belajar yang mereka manfaatkan dalam belajar. Perlu disadari bahwa alokasi waktu belajar di sekolah atau kampus terbatas. Waktu paling banyak justru dihabiskan di luar lingkungan itu.

F. Media dapat menumbuhkan sikap positif pebelajar terhadap materi dan proses belajar.

Dengan media pembelajaran, proses belajar menjadi lebih menarik. Sehingga mendorong peserta didik guna mencintai ilmu pengetahuan, serta mandiri dalam mencari sumber pengetahuan. Sehingga bisa menanamkan sikap mempunyai inisiatif sendiri ketika mencari berbagai sumber belajar yang diperlukan.

G. Mengubah peran pendidik ke arah lebih positif dan produktif.

Dengan memanfaatkan media pembelajaran secara baik, seorang pendidik bukan lagi menjadi satusatunya sumber belajar bagi peserta didik. Seorang pendidik tidak perlu menjelaskan seluruh materi pelajaran. Karena bisa berbagi peran dengan media. Dengan demikian, pendidik lebih banyak memiliki waktu untuk memberi perhatian dalam aspek edukatif lain. Misalnya, membantu kesulitan belajar, pembentukan kepribadian, memotivasi belajar dan lain-lain. 
H. Media dapat membuat materi pelajaran yang abstrak menjadi konkrit

Mengidentifikasi bentuk pasar dalam kegiatan ekonomi masyarakat misalnya, dapat dijelaskan melalui media gambar pasar dari tradisional sampai modern. Demikian pula materi pelajaran yang rumit bisa disajikan lebih sederhana dengan bantuan media. Misalnya, materi yang membahas pusat kerajaan Islam nusantara dapat menggunakan peta atau atlas. Sehingga peserta didik dengan mudah memahami pembelajaran tersebut.

I. Media dapat mengatasi kendala keterbatasan ruang dan waktu

Sesuatu yang di luar ruang kelas bisa disajikan di dalam kelas melalui bantuan media pembelajaran. Demikian pula beberapa peristiwa masa lampau, dapat disajikan di depan peserta didik sewaktu-waktu. Suatu peristiwa penting yang sedang terjadi di benua lain dapat dihadirkan seketika di kelas .
J. Media dapat membantu mengatasi keterbatasan indera manusia

Obyek materi pelajaran yang terlalu kecil, besar atau jauh dapat dipelajari melalui bantuan media. Demikian pula obyek berupa proses atau kejadian yang cepat atau lambat, dapat disaksikan dengan jelas melalui media. Dengan cara memperlambat atau mempercepat kejadian.

Media mobile learning berbasis android yang dikembangkan ini dapat mengatasi masalah yang dihadapi oleh pendidik. Tatkala proses pembelajaran dengan bantuan media, pendidik terbantu oleh sifat media yang praktis dan efisien. Terutama dalam menampilkan dan menyajikan materi pembelajaran. Hal ini diperkuat dengan hasil dari validasi oleh ahli pembelajaran, ahli materi dan juga oleh ahli desain media pembelajaran, seperti yang ditunjukkan pada tabel 5, tabel 6 dan tabel 7.

Tabel 5. Hasil Penilaian Ahli Pembelajaran

\begin{tabular}{|c|c|c|}
\hline No & Kriteria & Nilai \\
\hline 1. & Kesesuaian tema yang disajikan dalam media pembelajaran & 4 \\
\hline 2. & Ketepatan kemampuan akhir yang direncanakan dengan indikator & 4 \\
\hline 3. & Kesesuaian indikator dengan materi yang disajikan & 3 \\
\hline 4. & Sistematika uraian isi materi & 3 \\
\hline 5. & Penggunaan bahasa yang sesuai dengan pemahaman mahasiswa & 3 \\
\hline 6. & Penyajian materi merangsang aktivitas pembelajaran & 3 \\
\hline 7. & Penyajian materi bisa memberikan motivasi & 4 \\
\hline 8. & Penyajian materi dapat memberikan pengalaman baru & 4 \\
\hline 9. & Kesesuaian materi dengan soal latihan & 3 \\
\hline \multirow[t]{4}{*}{10.} & Instrumen evaluasi bisa mengukur kemampuan mahasiswa & 3 \\
\hline & Jumlah & 34 \\
\hline & $\mathrm{P}=\frac{\sum x}{\sum x i} \mathrm{x} 100 \%$ & $85 \%$ \\
\hline & Kriteria & Sangat Valid \\
\hline
\end{tabular}

(Dokumentasi Peneliti) 
Berdasarkan dari tabel 5 yang menunjukkan hasil penilaian oleh ahli pembelajaran tentang proses pengajaran sejarah Eropa, dengan menggunakan media mobile learning berbasis android diperoleh total skor 34 dengan nilai persentase $85 \%$.
Sehingga berada pada kriteria sangat valid. Hasil ini menunjukkan bahwa proses pembelajaran sejarah Eropa dengan menggunakan media mobile learning berbasis android sangat layak untuk digunakan pendidik.

Tabel 6. Hasil Penilaian Ahli Materi

\begin{tabular}{|c|c|c|}
\hline No & Kriteria & Nilai \\
\hline 1. & Kejelasan indikator & 4 \\
\hline 2. & Ketepatan indikator dengan kemampuan akhir yang direncanakan & 4 \\
\hline 3. & Ketepatan indikator dengan materi pembelajaran & 4 \\
\hline 4. & Keruntutan penyajian materi pembelajaran & 4 \\
\hline 5. & Keakuratan materi pembelajaran & 3 \\
\hline 6. & Kelengkapan materi pembelajaran yang disajikan & 3 \\
\hline 7. & Kejelasan atau keterbacaan pesan yang disampaikan & 3 \\
\hline 8. & Kesesuaian penggunaan kaidah bahasa & 4 \\
\hline 9. & Kesesuaian evaluasi pembelajaran & 4 \\
\hline 10. & Kejelasan soal/tes & 3 \\
\hline \multirow{2}{*}{\multicolumn{2}{|c|}{$\mathrm{P}=\frac{\sum x}{\sum x i} \mathrm{x} 100 \% \quad \mathrm{P}=\frac{36}{40} \times 100 \%$}} & 36 \\
\hline & & $90 \%$ \\
\hline \multicolumn{2}{|r|}{ Kriteria } & Sangat Valid \\
\hline
\end{tabular}

(Dokumentasi Peneliti)

Dari tabel 6 yang menunjukkan hasil penilaian oleh ahli materi tentang tema, konten isi dan materi sejarah Eropa yang disajikan dalam instrumen (alat) media mobile learning berbasis android, diperoleh total skor 36 dengan nilai persentase 90\%. Sehingga berada pada kriteria sangat valid. Hasil ini menunjukkan bahwa konten materi yang terdapat di media mobile learning berbasis android telah memenuhi syarat. Sehingga sangat layak untuk digunakan pendidik sebagai media pembelajaran.

\section{Tabel 7. Hasil Penilaian Ahli Desain Media Pembelajaran}

\begin{tabular}{|c|c|c|}
\hline No & Kriteria & Nilai \\
\hline 1. & Kemenarikan tampilan media pembelajaran & 4 \\
\hline 2. & Ketepatan tata warna yang digunakan & 3 \\
\hline 3. & Ketepatan penggunaan jenis huruf & 3 \\
\hline 4. & Ketepatan penggunaan ukuran huruf & 3 \\
\hline 5. & Background dapat mendukung tema materi pembelajaran & 4 \\
\hline 6. & Kejelasan audio atau suara & 3 \\
\hline 7. & Kejelasan petunjuk penggunaan media & 3 \\
\hline 8. & Kesesuaian gambar dengan materi pembelajaran & 4 \\
\hline 9. & Kejelasan paparan materi & 3 \\
\hline \multirow[t]{4}{*}{10.} & Kemudahan pengoperasian media pembelajaran & 4 \\
\hline & Jumlah & 34 \\
\hline & $P=\frac{34}{40} \times 100 \%$ & $85 \%$ \\
\hline & Kriteria & Sangat Valid \\
\hline
\end{tabular}

(Dokumentasi Peneliti) 
Tabel 7 yang menampilkan hasil penilaian ahli desain media pembelajaran yang memperoleh total skor 34, dengan nilai persentase $85 \%$, berada pada kriteria sangat valid. Hal ini bisa diartikan penggunaan media mobile learning berbasis android pada materi sejarah Eropa dapat meningkatkan motivasi dan, antusias peserta didik untuk belajar. Dengan meningkatnya motivasi belajar, maka hasil belajar juga dapat ditingkatkan.

Motivasi belajar merupakan dorongan yang berasal dari dalam atau luar diri manusia, sehingga dapat menimbulkan kegiatan belajar. Adanya motivasi dalam diri peserta didik mendorong mereka, aktif melakukan kegiatan belajar secara rutin dan terus-menerus. Apabila motivasi saat belajar tinggi maka mereka mudah dalam mencapai hasil belajar optimal. Oleh karena, seseorang yang ingin memperoleh prestasi belajar tinggi harus mempunyai motivasi yang tinggi untuk belajar. Motivasi bisa diperoleh melalui penggunaan media pembelajaran yang menarik.

Mengingat media yang disampaikan dengan cara menyenangkan, selain terdapat unsur penanaman karakter dan juga nyaman (Octavianto Nugroho Saputro \& Soebijantoro, 2015). Hal ini sesuai pendapat Slameto (2010) yang menyatakan faktor-faktor yang mempengaruhi prestasi belajar digolongkan menjadi dua yaitu faktor intern dan ektern. Salah satu faktor intern adalah motivasi belajar, sedangkan faktor ekstern adalah penggunaan media pembelajaran. Ketepatan penggunaan media pembelajaran dapat mondorong motivasi belajar peserta didik. Sehingga bisa meningkatkan hasil belajarnya. Semakin tinggi penggunaan media pembelajaran dan motivasi belajar, maka semakin tinggi pula hasil belajar yang diperoleh. Namun apabila penggunaan media pembelajaran dan motivasi belajar rendah, hasil belajar pun juga rendah.

Oleh karena, seorang pendidik atau Dosen berupaya untuk memilih media pembelajaran yang tepat. Tujuannya supaya motivasi belajar mahasiswa menjadi lebih terukur dan bisa meningkatkan hasil belajar secara teori dan praksisnya. Salah satu formulasi media yang dapat digunakan adalah media mobile learning berbasis android yang dikembangkan oleh penulis, yang sudah sesuai dengan hasil penilaian ahli di bidangnya. Selain itu, media yang dikembangkan sudah diterapkan dengan metode eksperimen dengan one group pretest \& post-test design.

Hasil dari metode tersebut, terdapat perbedaan yang signifikan antara hasil belajar sebelum dan setelah penerapan media mobile learning berbasis android materi sejarah revolusi industri du Eropa. Hal ini terukur dari nilai sig. (2-tailed) sebesar 0,000 atau lebih besar dari 0,05. Berdasarkan uraian tersebut dapat dimaknai bahwa penggunaan media mobile 
learning sejarah Eropa berbasis android secara efektif mampu meningkatkan hasil belajar mahasiswa angkatan 2017 kelas A Program Studi Pendidikan Sejarah dan Sosiologi IKIP Budi Utomo Malang.

\section{Penutup}

\section{A. Kesimpulan}

Media mobile learning berbasis android materi sejarah Eropa yang diterapkan pada mahasiswa kelas 2017 A memiliki nilai rata-rata hasil post-test lebih besar dari nilai rata-rata pre-test, yaitu $81,33>69,33$. Hasil uji paired samples test diketahui nilai sig. (2-tailed) 0,000 lebih besar dari 0,05, dan hasil $-t_{\text {hitung }}<-t_{\text {tabel }}$ yaitu $-12.692<-2,01537$. Sehingga dapat dinyatakan bahwa terdapat perbedaan signifikan antara hasil belajar sebelum dan setelah penerapan media mobile learning sejarah Eropa berbasis android. Untuk itu, media hasil pengembangan dengan efektif mampu meningkatkan hasil belajar mahasiswa angkatan 2017 kelas A Program Studi Pendidikan Sejarah Dan Sosiologi IKIP Budi Utomo Malang.

\section{B. Saran}

Perlu dilakukan penelitian lebih lanjut tentang penggunaan media mobile learning sejarah Eropa secara khusus atau pada kompetensi yang lain secara umum. Dengan terlebih dahulu memperhatikan permasalahan yang terdapat dalam proses pembelajaran. Bagi pendidik diharapkan untuk menggunakan media mobile learning materi sejarah Eropa berbasis android sebagai salah satu bahan sumber media pengajaran. Oleh karena terbukti dapat meningkatkan hasil belajar peserta didik.

\section{Daftar Pustaka}

Arifianto, T. (2011). Membuat Interface Aplikasi Android Lebih Keren dengan LWUIT. Yogyakarta: ANDI.

Arikunto, S. (2013). Prosedur Penelitian Suatu Pendekatan Praktek. Yogyakarta: Rineka Cipta.

Aritonang \& Satyaputra. (2014). Beginning Android Programming with ADT Budle. Jakarta: Elex Media Komputindo.

Arsyad, A. (2006). Media Pembelajaran. Jakarta: PT Raja Grafindo Persada.

Cholil, S. \& Kurniawan. (2011). Psikologi Pendidikan: Telaah Teoritik dan Praktik. Surabaya: IAIN Sunan Ampel Press.

Huda, A. A. (2013). Live Coding! 9 Aplikasi Buatan Sendiri. Yogyakarta: ANDI

Meilana, J. R. (2017). Pengembangan Modul Mobile Learning Berbasis Android Pada Materi Fluida Statis Siswa Sekolah Menengah Atas. Skripsi. Universitas Bandar Lampung

Rusman. (2012). Belajar dan Pembelajaran Berbasis Komputer. Bandung: Alfabeta.

Saputro, O. N. \& Soebijantoro. (2015). Pengembangan Wedus Gembel (Wayang Kardus Gembira Dan Belajar) Sebagai Media Membangun Jiwa Nasionalisme Sejak Dini Pada Siswa TKK Santo Yusuf Kota Madiun. Agastya: Jurnal Sejarah dan Pembelajarannya, 5(01), 99-117. http://doi.org/10.25273/ajsp.v5i02. 889.

Sardiman. (1992). Interaksi dan Motivasi Belajar Mengajar. Jakarta: Raja Grafindo Persada. 
Slameto. (2010). Belajar dan Faktor-faktor yang Mempengaruhinya. Jakarta: Rineka Cipta

Sugiyono. (2014). Metode Penelitian Kuantitatif. Kualitatif dan $R \& D$. Bandung: Alfabeta.

Sukiman. (2012). Pengembangan Media Pembelajaran. Yogyakarta: PT Pustaka Insan Madani.

Suranto. (2005). Komunikasi Perkantoran. Yogyakarta: Wahana Grafika.

Sutirman. (2013). Media dan Model-Model Pembelajaran Inovatif. Yogyakarta: Graha Ilmu.

Yamin, M. (2006). Strategi Pembelajaran Berbasis Kompetensi. Jakarta: Gaung Persada Press. 